\title{
Evaluation of the Outcomes of Gastrointestinal Endoscopic Examination in Patients with Iron Deficiency in the Light of Current Guidelines
}

\section{Demir Eksikliği Olan Hastalarda Gastrointestinal Endoskopik İnceleme Sonuçlarının Güncel Klavuzlar Eşliğinde Değerlendirilmesi}

\author{
Orhan Coşkun', @Mustafa Çapraz², Deynep Çetin³ \\ ${ }^{1}$ Amasya University, Sabuncuoğlu Şerefeddin Training and Research Hospital, Gastroenterology Department, Amasya, Turkey \\ 2 Amasya University, Sabuncuoğlu Şerefeddin Training and Research Hospital, Department of Internal Diseases, Amasya, Turkey \\ ${ }^{3}$ Amasya University Sabuncuoğlu Şerefeddin Training and Research Hospital, Endocrinology Department, Amasya, Turkey
}

\begin{abstract}
Introduction: Chronic blood loss and intestinal malabsorption of iron are two important causes of iron deficiency (ID) in adult patients. We evaluated the demographic data and endoscopy findings of patients who underwent endoscopic examination due to iron deficiency.

Material and Method: The study was designed retrospectively.The database of patients who underwent endoscopic examination due to ID and/or iron deficiency anemia (IDA) in the endoscopy unit of our hospital between June 2017-April 2020 were found by scanning the hospital database. After exclusion of patients with active bleeding, remaining 326 patients were evaluated.

Findings: Median age of the patients was 58 years. The participants included 182 males and 144 females. Ninety three patients were below 50 years of age whereas 133 patients were over 50 years old. Endoscopy (EGD) was performed in $13.2 \%$ of the patients; colonoscopy was performed in $2.5 \%$ of them; and endoscopy + colonoscopy (bidirectional procedure) was performed in $84.4 \%$. Endoscopic examinations revealed pathological findings that may cause ID/ IDA in $69.3 \%$ of the patients; however, no gastrointestinal pathology was detected in $30.7 \%$. Twelve patients were diagnosed with malign diseases. Detection of any pathology that may cause ID/IDA during endoscopic examinations was significantly more in the bidirectional examination group when compared to patients who had only EGD or colonoscopy $(p<0.001)$. Furthermore, concomitant pathologies in both lower and upper GIS were detected in $17.5 \%$ of the patients in the bidirectional examination group.
\end{abstract}

Conclusion: Bidirectional endoscopic examinations according to guideline recommendations increase diagnostic efficiency compared to one-sided examinations.

Keywords: Iron deficiency, anemia, endoscopy, colonoscopy
Öz

Giriş: Erişkin hastalarda kronik kan kaybı ve demirin intestinal emilim bozukluğu demir eksikliğinin (DE) iki önemli nedenidir. Bu çalışmamızda demir eksikliği nedeniyle endoskopik inceleme yaptığımız hastaların demografik verilerini ve endoskopi bulgularımızı değerlendirdik.

Gereç ve Yöntem: Çalışma retrospektif olarak dizayn edildi. Haziran 2017-Nisan 2020 tarihleri arasında hastanemiz endoskopi ünitesinde DE ve/veya DEA nedeniyle endoskopik inceleme yapılan hastalar veri tabanı taranarak bulundu. Aktif kanama bulgusu olan hastalar dışlandıktan sonra kalan 326 hasta değerlendirildi.

Bulgular: Hastaların median yaşı 58'di. 182'si erkek (\%55,8), 144'ü kadındı $(\% 44,2)$. Hastaların \%28,5'i $(n=93) 50$ yaş ve altında iken, \%71,5'i ( $n=133)$ 50 yaşın üzerindeydi. \%13,2'sine endoskopi (ÖGD), \%2,5'ine kolonoskopi, $\% 84,4$ 'üne endoskopi+kolonoskopi (çift yönlü işlem) birlikte yapılmıştı. Yapılan endoskopik incelemeler sonrasında hastaların \%69,3'ünde DE/ DEA'ya neden olabilecek patolojik bulgular saptanırken \%30,7'sinde DE/ DEA'ya neden olabilecek sindirim kanalı patolojisi izlenmedi. Hastaların 12 'sinde $(\% 3,8)$ malignite saptandı. Endoskopik incelemeler esnasında DE/ DEA'ya neden olabilecek herhangi bir patoloji saptanmasl; sadece ÖGD veya kolonoskopi yapılan hastalarla $(\% 43,1)$ karşılaştıııldığında; çift yönlü inceleme yapılan hasta grubunda $(\% 74,2)$ istatistiksel olarak daha fazlaydı $(p<0,001)$. Ayrıca çift yönlü inceleme yapılan hastaların \%17,5'inde hem alt hem de üst GiS'te DE/DEA'ya neden olabilecek eş zamanlı patoloji saptandı.

Sonuç: Klavuzlarda önerildiği şekilde endoskopik incelemelerin çift yönlü yapılması, tek yönlü incelemelere göre tanısal etkinliği artırır.

Anahtar kelimeler: Demir eksikliği, anemi, endoskopi, kolonoskopi

Corresponding (iletişim): Orhan Coşkun, Amasya University, Sabuncuoğlu Şerefeddin Training and Research Hospital, Gastroenterology Department, Amasya, Turkey

E-mail (E-posta): drcoskunorhan@gmail.com

Received (Geliş Tarihi): 04.04.2021 Accepted (Kabul Tarihi): 08.08.2021 


\section{INTRODUCTION}

The World Health Organization defines anemia when hemoglobin $(\mathrm{Hb})$ concentration below $13 \mathrm{~g} / \mathrm{dl}$ in adult males, less than $12 \mathrm{~g} / \mathrm{dl}$ in adult non-pregnant females, and less than $11 \mathrm{~g} / \mathrm{dl}$ in pregnant women. ${ }^{[1]}$ Iron deficiency anemia (IDA) is the most common anemia type all over the world. It is detected in $2 \%$ to $5 \%$ of men and post-menopausal women in developed countries. ${ }^{[1,2]}$

Absorption of dietary iron mostly occurs in duodenum and proximal jejunum. ${ }^{[3]}$

Insufficient dietary iron intake, impaired intestinal absorption of iron or conditions that cause chronic blood loss lead to iron deficiency. ${ }^{[1,3]}$ In addition, common causes for IDA include phlebotomy, gastrectomy and use of non-steroidal antiinflammatory drugs (NSAIDs). ${ }^{[1]}$

Serum markers of iron deficiency (ID) are low ferritin, low transferrin saturation, low iron, increased total iron binding capacity, increased alveolar zinc protoporphyrin level and increased serum transferrin receptor (sTfR) levels. Serum ferritin level is the strongest test to indicate IDA. In order to diagnose iron deficiency in patients with anemia, the threshold value for ferritin level has been reported as $15 \mathrm{ng} / \mathrm{mL}^{[1,3]}$

Chronic blood loss and impaired intestinal absorption of iron are two important causes of ID. Such both conditions are closely related to the gastrointestinal (GI) tract. ${ }^{[4]} \mathrm{Gl}$ lesions were shown in $40 \%$ to $70 \%$ of adult males and post-menopausal females with IDA in the etiology. In these studies, increased age, male gender, low ferritin level, the use of NSAID, positive fecal occult blood test, and presence of $\mathrm{Gl}$ symptoms were stated as predictors of endoscopic lesions..$^{[5]}$

IDA is accepted as an alarm sign for GI malignancy. Inadequate evaluation of patients with IDA may delay the diagnosis of GI tumors, especially colorectal cancer.$^{[5]}$ The American guideline (AGA) also stated that gastrointestinal malignancy is the most serious potential cause of IDA. ${ }^{[3]}$

Both AGA and English (BSG) guidelines recommend bidirectional endoscopic evaluation (both esophagogastroduodenoscopy (EGD) and colonoscopy) at the same time in order to evaluate post-menopausal females and males. ${ }^{[1,3]}$ BSG recommends that premenopausal women under the age of fifty undergo colonoscopy if they have colonic symptoms, and if there is persistant IDA despite iron therapy. However, the AGA guideline recommends bidirectional endoscopic evaluation in premenopausal women with IDA. ${ }^{[1,3]}$

We evaluated the demographic data and endoscopy findings of patients who underwent endoscopic examination of upper and lower GI tract because of ID and/or IDA.

\section{MATERIAL AND METHOD}

Totally 326 patients who underwent endoscopic examination due to ID and/or IDA in the endoscopy unit of our hospital between June 2017 and April 2020 were evaluated. Patient age, gender, use of NSAIDs and anticoagulants, hemoglobin, hematocrit, iron, total iron binding capacity, ferritin levels at the time of endoscopy, endoscopic diagnosis, and biopsy results were evaluated. Patients younger than 18 years old and patients with active bleeding findings such as melena were not included in the study.

All endoscopic procedures were performed by a single specialist. Malignancies, erosive esophagitis and gastritis, esophageal varices and portal hypertensive gastropathy $(\mathrm{PHG})$, ulcer detected in any localization, gastrectomy, polyp, angiodysplasia, appearance of celiac disease, inflammatory bowel disease (IBD), diverticules, hemorrhoids, and anal fissure diagnoses during endoscopic examination were recorded. Our study was carried out according to Helsinki declaration. Approval of the ethical committee for the study was obtained with E.11346 numbered on July 15th,2020.

\section{Statistical Analysis}

Statistical evaluation was performed by the Statistical Package for Social Sciences (SPSS) for Windows 20 (IBM SPSS Inc., Chicago,IL) program. Normal distribution of the data was evaluated by Kolmogorov-Smirnov test. Descriptive statistical methods (mean, standard deviation, median, frequency, ratio, minimum, maximum) were used for evaluation of the study data.

Pearson Chi-Square test and Fisher's Exact test were used for comparison of the qualitative data.

Any p level below 0.05 was evaluated at significance level.

\section{RESULTS}

The study population included 144 (44.2\%) females and 182 (55.8\%) males. The ages of the cases were between 18 and 89 years. The average age was $58.85 \pm 14.52$ years. Ninety three (28.5\%) patients were below 50 years of age whereas 133 (71.5\%) patients were above 50 years of age. The review of past-medical history of the patients was shown in Table $\mathbf{1}$. Analysis of laboratory parameters was represented in Table $\mathbf{2}$. Ten (10.4\%) of 96 patients whose stool occult blood (SOB) tests were examined were detected positive for SOB. Furthermore, parasite eggs were found in 2 (3.1\%) of 65 patients who were examined for stool parasites (Table 2).

Endoscopic examinations revealed pathological findings that may cause ID/IDA in $69.3 \%(n=226)$ of the patients; however, no pathology was detected in $30.7 \%(n=100)$. While no pathology was found in $63.5 \%$ of the patients by EGD evaluations, erosive gastritis was the most common upper GIS pathology. No pathology was found in $42.7 \%(n=120)$ of the patients who had colonoscopy examinations and the polyps were the most common lesions (Table 3).

Celiac disease was diagnosed in $7(10.9 \%)$ of $64(20.1 \%)$ patients whose celiac biopsy was collected for screening. All these 7 patients had endoscopic appearance compliant to Celiac disease. Biopsy was collected from 213 (67\%) of 318 
patients during the EGD examinations for the analysis of Helicobacter pylori (HP) and pathological examination. Among these patients, HP was detected in $62.4 \%(n=133)$, and atrophy in $27.2 \%(n=58)$ of the patients (Table 3$)$.

Anamnesis of the patients who had no pathology in the endoscopic examinations revealed that 5 patients were blood donors and 1 patient had medical leech and cupping therapies (Table 3).

Forty-three (13.2\%) patients had EGD only, 8 (2.5\%) patients had colonoscopy only, and 275 (84.4\%) patients had EGD and colonoscopy (bidirectional) examinations. Detection of any pathology that may cause ID/IDA endoscopically was significantly more in the bidirectional examination group (43.1\%) when compared to patients who had unidirectional procedure $(74.2 \%)(p<0.01)$ (Table 4). Furthermore, $48(17.5 \%)$ patients who underwent EGD and colonoscopy together

\begin{tabular}{|c|c|c|c|}
\hline & & $\mathbf{n}$ & $\%$ \\
\hline \multirow{4}{*}{ Age (years) } & Min-Max (Medyan) & \multicolumn{2}{|c|}{$18-89$} \\
\hline & Mean \pm Sd & \multicolumn{2}{|c|}{$56.85 \pm 14.52$} \\
\hline & $\leq 50$ age & 93 & 28.5 \\
\hline & $\geq 50$ age & 133 & 71.5 \\
\hline \multirow{2}{*}{ Gender } & Female & 144 & 44.2 \\
\hline & Male & 182 & 55.8 \\
\hline \multirow{9}{*}{$\begin{array}{l}\text { Comorbid } \\
\text { diseases }\end{array}$} & No & 135 & 41.4 \\
\hline & Ischemic heart disease & 40 & 12.5 \\
\hline & Diabetes mellitus & 55 & 16.9 \\
\hline & Hypertension & 59 & 18.1 \\
\hline & COPD & 2 & 0.6 \\
\hline & CVA & 2 & 0.6 \\
\hline & Liver cirrhosis & 8 & 2.5 \\
\hline & Arrhythmia & 5 & 1.5 \\
\hline & Other & 20 & 6.1 \\
\hline \multirow{8}{*}{$\begin{array}{l}\text { Antithrombotic } \\
\text { drug use }\end{array}$} & No & 245 & 75.2 \\
\hline & Acetyl salicylic acid & 40 & 12.3 \\
\hline & Clopidogrel & 19 & 5.8 \\
\hline & Warfarin & 2 & 0.6 \\
\hline & Apixaban & 3 & 0.9 \\
\hline & Acetyl salicylic acid + Clopidogrel & 4 & 1.2 \\
\hline & Acetyl salicylic acid + Ticagrelor & 7 & 2.1 \\
\hline & Other & 6 & 1.8 \\
\hline NSAID use & $\begin{array}{l}\text { Yes } \\
\text { No }\end{array}$ & $\begin{array}{l}107 \\
219\end{array}$ & $\begin{array}{l}32.8 \\
67.2\end{array}$ \\
\hline COPD: chronic obstru & ive pulmonary disease, CVA: cerebrovascular ac & & \\
\hline
\end{tabular}

\begin{tabular}{lcc}
\multicolumn{3}{l}{ Table 2. Laboratory parameters of patients with DE / IDA } \\
\hline & Min-Max & Mean \pm Std. Deviation \\
\hline Hemoglobin (g/dL) & $5.7-15.3$ & $11.61 \pm 1.85$ \\
Hematocrit (\%) & $19.8-48.7$ & $36.7 \pm 4.8$ \\
Platelet (x109) & $87000-668000$ & $262760 \pm 79.8$ \\
MCV (fL) & $53.4-98.8$ & $79.1 \pm 7.4$ \\
Serum Iron (ug / dL) & $6-207$ & $44.1 \pm 30.7$ \\
TIBC (ug / dL) & $55-731$ & $370.74 \pm 88.5$ \\
Serum Ferritin (ug / L) & $1.5-169$ & $14.92 \pm 17.3$ \\
Vitamin B12 (ng / L) & $100-2000$ & $360.16 \pm 223.3$ \\
Folate (ug / L) & $1.7-304$ & $11.8 \pm 26.4$ \\
FOBT & 10 & \\
Stool parasite (n: 65) & 2 & \\
\hline MCV: Mean corpusculer volüme, TIBC: Total iron binding capacity, FOBT: Fecal occult blood test
\end{tabular}

revealed concomitant pathologies that may cause ID/IDA (Table 3).

When the patients were grouped according to the age as below 50 years $(n=93)$ and above 50 years $(n=233)$, no statistically significant difference was found between the groups for gender, NSAID use, malignancy, celiac disease, HP positivity, and atrophy ( $>0.05$ ). In the patient group above 50 years of age, findings such as comorbid diseases, use of anticoagulants, bidirectional endoscopic procedures, endoscopic diagnosis, concomitant pathology in the lower and upper GIS were detected more in the group younger than 50 years $(p<0.001)$. The rate for biopsy from the duodenum was higher in the group younger than 50 years than the other group $(p<0.001)$ (Table 5).

The analyzes in Table 5 were made by grouping female patients as younger than 50 years old and 50 years and above (Table 6).

Table 3. Endoscopic examination findings in all patients with iron deficiency

\begin{tabular}{|c|c|c|c|}
\hline & & n & $\%$ \\
\hline Endoscopic procedure & $\begin{array}{l}\text { Endoscopy } \\
\text { Colonoscopy } \\
\text { Endoscopy + Colonoscopy }\end{array}$ & $\begin{array}{c}43 \\
8 \\
275\end{array}$ & $\begin{array}{c}13.2 \\
2.5 \\
84.4\end{array}$ \\
\hline $\begin{array}{l}\text { Endoscopy findings } \\
\text { (n: 318) }\end{array}$ & $\begin{array}{l}\text { No pathology } \\
\text { Gastric ulcer } \\
\text { Erosive Gastritis } \\
\text { Duodenal ulcer } \\
\text { Gastric cancer } \\
\text { Polyp } \\
\text { Angiodysplasia } \\
\text { GIST } \\
\text { Esophagitis } \\
\text { PHG / Varicose Veins } \\
\text { Celiac disease } \\
\text { Operation history }\end{array}$ & $\begin{array}{c}202 \\
15 \\
32 \\
9 \\
5 \\
17 \\
4 \\
2 \\
11 \\
5 \\
7 \\
9 \\
\end{array}$ & $\begin{array}{c}63.5 \\
4.7 \\
10.1 \\
2.8 \\
1.6 \\
5.3 \\
1.3 \\
0.6 \\
3.5 \\
1.6 \\
2.2 \\
2.8 \\
\end{array}$ \\
\hline $\begin{array}{l}\text { Colonoscopy findings } \\
\text { (n: 281) }\end{array}$ & $\begin{array}{l}\text { No pathology } \\
\text { Polyp } \\
\text { Colon cancer } \\
\text { Hemorrhoids } \\
\text { Angiodysplasia } \\
\text { Solitary rectal ulcer } \\
\text { Colon diverticulum } \\
\text { Colitis / ileitis / IBD } \\
\text { Anal fissure }\end{array}$ & $\begin{array}{c}120 \\
56 \\
5 \\
46 \\
11 \\
2 \\
18 \\
7 \\
16\end{array}$ & $\begin{array}{c}42.7 \\
19.9 \\
1.8 \\
16.4 \\
3.9 \\
0.7 \\
6.4 \\
2.5 \\
5.7\end{array}$ \\
\hline $\begin{array}{l}\text { Simultaneous pathology } \\
\text { in upper and lower GIS } \\
\text { (n: 275) }\end{array}$ & $\begin{array}{l}\text { Yes } \\
\text { No }\end{array}$ & $\begin{array}{c}48 \\
227\end{array}$ & $\begin{array}{l}17.5 \\
82.5\end{array}$ \\
\hline $\begin{array}{l}\text { Diagnosis by endoscopic } \\
\text { examination }\end{array}$ & $\begin{array}{l}\text { Yes } \\
\text { No }\end{array}$ & $\begin{array}{l}226 \\
100\end{array}$ & $\begin{array}{l}69.3 \\
30.7\end{array}$ \\
\hline Celiac biopsy (n: 318) & $\begin{array}{l}\text { Yes } \\
\text { No }\end{array}$ & $\begin{array}{c}64 \\
254\end{array}$ & $\begin{array}{l}20.1 \\
79.9\end{array}$ \\
\hline HP biopsy (n: 213) & $\begin{array}{l}\text { There is } \\
\text { No }\end{array}$ & $\begin{array}{c}133 \\
80\end{array}$ & $\begin{array}{l}62.4 \\
37.6\end{array}$ \\
\hline Atrophy (n: 213) & $\begin{array}{l}\text { There is } \\
\text { No }\end{array}$ & $\begin{array}{c}58 \\
155\end{array}$ & $\begin{array}{l}27.2 \\
72.8\end{array}$ \\
\hline Other Causes & $\begin{array}{l}\text { Phlebotomy } \\
\text { Leech therapy / cupping } \\
\text { theraphy }\end{array}$ & $\begin{array}{l}5 \\
1\end{array}$ & $\begin{array}{l}1.5 \\
0.3\end{array}$ \\
\hline
\end{tabular}

Table 4. Endoscopic diagnosis by unidirectional and bidirectional endoscopic examination

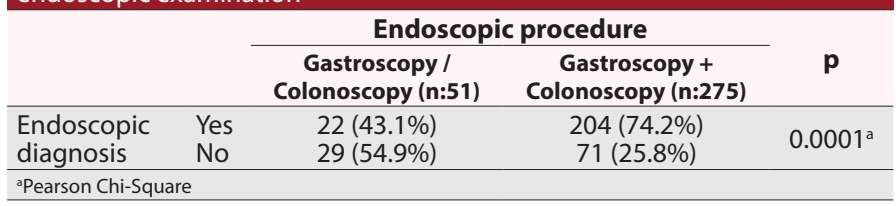




\begin{tabular}{|c|c|c|c|c|}
\hline & & $\leq 50$ age $(\mathrm{n}: 93)$ & $>50$ age $(n: 233)$ & $\mathbf{p}$ \\
\hline Gender & $\begin{array}{l}\text { Female } \\
\text { Male }\end{array}$ & $\begin{array}{l}42(45.2 \%) \\
51(54.8 \%)\end{array}$ & $\begin{array}{l}102(43.8 \%) \\
131(56.2 \%)\end{array}$ & $0.82^{\mathrm{a}}$ \\
\hline Comorbid diseases & $\begin{array}{l}\text { Yes } \\
\text { No }\end{array}$ & $\begin{array}{l}24(25.8 \%) \\
69(74.2 \%)\end{array}$ & $\begin{array}{l}167(71.7 \%) \\
66(28.3 \%)\end{array}$ & $0.0001^{\mathrm{a}}$ \\
\hline Antithrombotic drug use & $\begin{array}{l}\text { Yes } \\
\text { No }\end{array}$ & $\begin{array}{c}4(4.3 \%) \\
89(95.7 \%)\end{array}$ & $\begin{array}{c}77(33 \%) \\
156(67\end{array}$ & $0.0001^{\mathrm{a}}$ \\
\hline NSAID use & $\begin{array}{l}\text { Yes } \\
\text { No }\end{array}$ & $\begin{array}{l}32(34.4 \%) \\
61(65.6 \%)\end{array}$ & $\begin{array}{l}75(32.2 \%) \\
158(67.8 \%)\end{array}$ & 0.7 \\
\hline Endoscopic procedures & $\begin{array}{l}\text { Unidirectional } \\
\text { Bidirectional }\end{array}$ & $\begin{array}{l}28(30.1 \%) \\
65(69.9 \%)\end{array}$ & $\begin{array}{c}23(9.9 \%) \\
210(90.1 \%)\end{array}$ & $0.0001^{\mathrm{a}}$ \\
\hline Duodenal biopsy (n:318) & $\begin{array}{l}\text { received } \\
\text { not received }\end{array}$ & $\begin{array}{l}46(49.5 \%) \\
47(50.5 \%)\end{array}$ & $\begin{array}{c}18(8 \%) \\
207(92 \%)\end{array}$ & $0.0001^{\mathrm{a}}$ \\
\hline Endoscopic diagnosis & $\begin{array}{l}\text { Yes } \\
\text { No }\end{array}$ & $\begin{array}{l}51(54.8 \%) \\
42(45.2 \%)\end{array}$ & $\begin{array}{l}175(75.1 \%) \\
58(24.9 \%)\end{array}$ & $0.001^{\mathrm{a}}$ \\
\hline Malignancy diagnosis & $\begin{array}{l}\text { Yes } \\
\text { No }\end{array}$ & $\begin{array}{c}1(1.1 \%) \\
92(98.9 \%)\end{array}$ & $\begin{array}{c}11(4.7 \%) \\
222(95.3 \%)\end{array}$ & $0.19^{b}$ \\
\hline Celiac diagnosis (n:318) & $\begin{array}{l}\text { Yes } \\
\text { No }\end{array}$ & $\begin{array}{c}4(4.3 \%) \\
89(95.7 \%)\end{array}$ & $\begin{array}{c}3(1.3 \%) \\
222(98.7 \%)\end{array}$ & $0.2^{\mathrm{b}}$ \\
\hline Simultaneous pathology in upper and lower GIS & $\begin{array}{l}\text { Yes } \\
\text { No }\end{array}$ & $\begin{array}{c}4(6.2 \%) \\
6193.8 \%)\end{array}$ & $\begin{array}{c}44(21 \%) \\
166(79 \%)\end{array}$ & $0.006^{\mathrm{a}}$ \\
\hline Helicobacter pylori (n:213) & $\begin{array}{l}\text { Positive } \\
\text { Negative }\end{array}$ & $\begin{array}{l}51(69.9 \%) \\
22(30.1 \%)\end{array}$ & $\begin{array}{l}82(58.6 \%) \\
58(41.4 \%)\end{array}$ & 0.1 \\
\hline Atrophy (n:213) & $\begin{array}{l}\text { There is } \\
\text { No }\end{array}$ & $\begin{array}{l}19(26 \%) \\
54(74 \%)\end{array}$ & 39 ( $27.9 \%) 101$ (72.1\%) & 0.7 \\
\hline Phlebotomy/Leech therapy / cupping therapy & $\begin{array}{l}\text { Yes } \\
\text { No }\end{array}$ & $\begin{array}{c}6(6.5 \%) \\
87(93.5 \%)\end{array}$ & $\begin{array}{c}0 \\
233(100 \%)\end{array}$ & $0.0001^{\mathrm{b}}$ \\
\hline
\end{tabular}

Table 6. Endoscopic examination findings of patients by age in women

\begin{tabular}{|c|c|c|c|c|}
\hline & & $\leq 50$ age $(n: 42)$ & $>50$ age $(n: 102)$ & $\mathbf{P}$ \\
\hline Comorbid diseases & $\begin{array}{l}\text { Yes } \\
\text { No }\end{array}$ & $\begin{array}{l}11(26.2 \%) \\
31(73.8 \%)\end{array}$ & $\begin{array}{l}78(76.5 \%) \\
24(23.5 \%)\end{array}$ & $0.0001^{\mathrm{a}}$ \\
\hline Antithrombotic drug use & $\begin{array}{l}\text { Yes } \\
\text { No }\end{array}$ & $\begin{array}{c}0 \\
42(100 \%)\end{array}$ & $\begin{array}{l}29(28.4 \%) \\
73(71.6 \%)\end{array}$ & $0.0001^{\mathrm{a}}$ \\
\hline NSAID use & $\begin{array}{l}\text { Yes } \\
\text { No }\end{array}$ & $\begin{array}{l}17(40.5 \%) \\
25(59.5 \%)\end{array}$ & $\begin{array}{l}40(39.2 \%) \\
62(60.8 \%)\end{array}$ & 0.88 \\
\hline Endoscopic procedures & $\begin{array}{l}\text { Unidirectional } \\
\text { Bidirectional }\end{array}$ & $\begin{array}{l}20(47.6 \%) \\
22(52.4 \%)\end{array}$ & $\begin{array}{c}10(9.8 \%) \\
92(90.2 \%)\end{array}$ & $0.0001^{\mathrm{a}}$ \\
\hline Endoscopic diagnosis & $\begin{array}{l}\text { There is } \\
\text { No }\end{array}$ & $\begin{array}{l}21(50 \%) \\
21(50 \%)\end{array}$ & $\begin{array}{l}71(69.6 \%) \\
31(30.4 \%)\end{array}$ & $0.002^{\mathrm{a}}$ \\
\hline Malignancy diagnosis (144) & $\begin{array}{l}\text { Yes } \\
\text { No }\end{array}$ & $\begin{array}{c}1(2.4 \%) \\
41(97.6 \%)\end{array}$ & $\begin{array}{c}4(3.9 \%) \\
98(96.1 \%)\end{array}$ & $0.1^{\mathrm{b}}$ \\
\hline Celiac diagnosis (n:141) & $\begin{array}{l}\text { Yes } \\
\text { No }\end{array}$ & $\begin{array}{c}2(4.8 \%) \\
40(95.2 \%)\end{array}$ & $\begin{array}{c}2(2 \%) \\
97(98 \%)\end{array}$ & $0.58^{b}$ \\
\hline Atrophy (n:93) & $\begin{array}{l}\text { There is } \\
\text { No }\end{array}$ & $\begin{array}{c}6(18.2 \%) \\
27(81.8 \%)\end{array}$ & $\begin{array}{c}24(40 \%) \\
36(60 \%)\end{array}$ & 0.003 \\
\hline
\end{tabular}

\section{DISCUSSION}

Iron deficiency anemia is the most common anemia type all over the world. ${ }^{[6]}$ The cause for endoscopic examination is IDA in $4 \%$ to $13 \%$ of the patients. ${ }^{[7]}$

Both AGA and BSG guidelines stated that serum ferritin level is the strongest test to indicate iron deficiency. The guidelines determined the threshold level of ferritin for IDA as $15 \mathrm{ng} / \mathrm{ml}{ }^{[1,3]}$ The mean ferritin level was detected $14.9 \mathrm{ng} / \mathrm{ml}$ in our study in line with the guidelines. The cause for higher ferritin level in our patients was initiation of iron replacement treatment by primary healthcare centers for the patients referred to our hospital (Table 1).

The most common cause of IDA is menstruation in premenopausal women, and blood loss from gastrointestinal system for men and post-menopausal women. ${ }^{[6]}$ Bidirectional endoscopy is recommended by BSG and AGA guidelines for post-menopausal female patients and male patients with IDA. ${ }^{[1,3]}$ 
Çetinkaya et al. ${ }^{[7]}$ detected the rate of not finding any pathology that may be cause of IDA in patients who underwent unidirectional procedures as $18.75 \%$ in gastroscopy and $46.55 \%$ in colonoscopy. However, the rate of not finding any pathology for bidirectional procedures was found $3.48 \%$.

In the study above, gastroscopy was performed in $59 \%$ of the patients, colonoscopy was performed in $23.8 \%$ of the patients, and both procedures were performed together in a very small portion by $17.2 \% \cdot{ }^{[4]}$ In our study, majority of the patients underwent bidirectional procedures in line with the guidelines (84.4\%). Bidirectional endoscopic examination was recommended for most of the patients who had only underwent EGD; however, some patients did not accept colonoscopic examination. Detection of any etiological cause for ID/IDA during endoscopic examinations was significantly more in the bidirectional examination group (74.2\%) when compared to patients who had EGD or colonoscopy individually $(43.1 \%)(p<0.001)$.

Presence of any significant cause for bleeding in upper and lower GIS (double pathology) was reported in $1 \%$ to $10 \%$ of the patients..$^{[1]}$ Hovewer, in our study 48 (17.5\%) patients who underwent EGD and colonoscopy together revealed concomitant pathologies that may cause ID/IDA.

Many possible causes exist in the etiology of IDA; however, gastrointestinal system malignancies are primary diagnoses that should be noted ${ }^{[4]}$ In a meta-analysis including 18 studies on the diagnostic efficiency of bidirectional endoscopy in postmenopausal women and men with IDA, the malignancy rate in the lower GIS was $8.9 \%$ and in the upper GIS was $2 \% .{ }^{[8]}$ Furthermore, a previous study including 695 patients detected malignancy in the GIS in $11.2 \%$ of the patients. In that study above, risk factors were age above 50 years, a $\mathrm{Hb}$ level at and below $9 \mathrm{gr} / \mathrm{dl}$, and male gender. ${ }^{[9]}$ Unal et al. detected that $0.9 \%$ of the patients who underwent EGD, and $4.7 \%$ of the patients who underwent colonoscopy were diagnosed with adenocancer. Yaylaci et al. detected that gastric cancer was detected in $10(7.7 \%)$ patients by EGD, and in $6(9.5 \%)$ patients by colonoscopy. In our study, malignancy was detected in $3.8 \%(n=12)$ of the patients. These were gastric adenocancer $(n=5)$, GIST $(n=2)$ and colonic adenocancer $(n=5)$. Malignancy rates were found lower than those reported in the literature. We considered the possible cause as our study population including those with both anemia and iron deficiency. In addition, exclusion of patients with active bleeding from the study may be effective in this situation.

Age is the strongest predictor of the pathology in patients with IDA. It was stated that age over 50 years is a significant risk factor for malignancy. ${ }^{[1,10]}$ The BSG guideline recommends colonoscopy in women under the age of 50 years, if there are colonic symptoms, strong family history, or if there is an ongoing IDA despite iron replacement therapy; however, the AGA guideline recommends bidirectional endoscopic examination in asymptomatic premenopausal women with IDA. ${ }^{[1,3]}$ When female patients were grouped according to the age as below 50 years $(n=42)$ and above 50 years $(n=102)$ in our study, no statistically significant difference was found between the groups for gender, NSAID use, malignancy, celiac disease, HP positivity, and atrophy ( $p>0.05)$. One female patient below 50 years was diagnosed with gastric cancer. Findings such as comorbid diseases, use of anticoagulants, the rate for diagnosis established endoscopically, concomitant pathology in the lower and upper GIS, and the rate of atrophy in biopsy samples collected during EGD were detected more in the patient group at and above 50 years of age. The higher rates of diagnosis established endoscopically in patients older than 50 years of age supported the recommendation of BSG guideline for avoiding unnecessary endoscopic examination and possible complications.

However, due to the lack of difference between the malignancy rates between the groups, the lower complication rate and lower endoscopic procedure costs in our country, it seems reasonable to perform bidirectional endoscopic examination according to the recommendation of the AGA guideline.

Celiac disease is a well-known cause for IDA even in asymptomatic patients and should be noted for differential diagnosis of IDA. ${ }^{[3]}$ The BSG and AGA guidelines recommend serological tests for Celiac disease in patients with IDA, and small intestine biopsy if the serological test is positive $(1,3)$. In the study conducted by Emami et al., the frequency of celiac disease was found $10 \%$ in duodenal biopsy samples collected from 130 patients with ID without visible explanatory endoscopic findings. Unal et al. detected the rate for villous atrophy as $4.8 \%$ in their study ${ }^{[4]}$ Karnam et al. detected the prevalence of occult celiac disease as $2.8 \%$ in their prospective study including patients referred due to IDA (11).In line with the literature, the rate of Celiac disease was $2.2 \%$ in our study.

Helicobacter pylori (HP) infection is associated with atrophic gastritis and hypochlorhydria which may reduce iron absorption. ${ }^{[3]}$ Hudak et al. reported in their meta-analysis including 14 studies that the probability of iron deficiency anemia is higher in individuals infected with HP when compared with those who were not infected by HP. ${ }^{[12]}$ In addition, Lee et al. stated in their meta-analysis that the incidence of gastric cancer is lower in individuals who received eradication treatment for HP infection than those who did not receive any eradication treatment, and this was reported as a significant situation for ID treatment. ${ }^{[13]} \mathrm{HP}$ eradication is a consensus decision in unexplained IDA. ${ }^{[14]}$ The AGA guideline recommends performing a non-invasive test for $\mathrm{HP}$ in patients with IDA without an identifiable etiology after bilateral endoscopic examination, and then, if positive, treatment without invasive testing. HP infection was detected in 35\% of the patients with ID, and $51 \%$ of the patients with IDA in the study conducted by Cardenas et al. In that study above, Cardenas et al. stated that a significant part of ID and IDA prevalences ( $14 \%$ and $32 \%$, respectively) may be associated with H. pylori infection. ${ }^{[15]}$ Cetinkaya et al. found HP positive in $66 \%$ of the patients with pangastritis by gastroscopy. ${ }^{[7]}$ In line with the literature, biopsy was collected from 213 (67\%) of 318 patients during the EGD examinations for the analysis of 
HP and pathological examination in the present study. Among the patients whom biopsy was taken, HP was detected positive by $62.4 \%(n=133)$, and eradication treatment was prescribed for those patients.

The AGA guideline recommends routine gastric biopsies to diagnose atrophic gastritis in patients with IDA. ${ }^{[3]}$ The rate of atrophy was found significantly higher in patients with IDA compared to the control group in the study conducted by Kaye et al. ( $p<0.001)$. They suggested that gastric atrophy is strongly associated with IDA and that biopsies should be taken especially from the corpus part of the stomach. ${ }^{[16]}$ Biopsy was collected from 213 (67\%) of 318 patients during the EGD examinations in our study. Among the patients whom biopsy was taken, atrophy was detected in $27.2 \%$ $(n=58)$ of the patients. No age difference was found between patients with and without atrophy in the anemic group in the study conducted by Kaye et al. When the patients were grouped according to the age as below 50 years and above 50 years in our study, no statistically significant difference was found between the groups ( $p>0.05$ ). However, atrophy rate was more in female patient group over 50 years of age than those younger than 50 years. We thought that the possible cause might be related due to the higher rate of comorbid diseases in this group and the use of more proton pump inhibitors. However, we could not investigate this factor due to retrospective design of our study.

Gastrectomies and achlorhydria are two other important conditions that impair iron absorption. IDA is a very common condition in patients with partial or total gastrectomy. ${ }^{[17]}$ Beyan et al. found IDA in $94.4 \%$ of the patients who underwent gastrectomy. ${ }^{[18]}$ In our study, gastrectomy was found as an etiological cause in $2.8 \%(n=9)$ of 318 patients who underwent EGD.

The BSG guideline states that the fecal occult blood test (FOBT) is useless in the investigation of ID and IDA, and it is an insensitive and nonspecific test. ${ }^{[1]}$ In our study, FOBT was performed in $29.4 \%(n=96)$ of all patients and only $10(10.4 \%)$ of these patients were FOBT positive. The test being negative in $90 \%$ of the patients indicates that it is not useful as in the literature.

It was stated in the BSG guidelines that there was no significant difference in the prevalence of $\mathrm{Gl}$ cancer in patients who received aspirin or warfarin alone or in combination when compared to patients who have not taken these drugs. Therefore, the guideline indicates that IDA should not be associated with such drugs until GIS researches are completed. ${ }^{[1]}$ In our study, $24.8 \%$ of the patients had history of previous single or multiple anticoagulant drug use. Four (33.3\%) patients whom malignancy was detected had history of concomitant use of anticoagulant/antiaggregant drugs.

The AGA guideline recommends the evaluation of underlying etiologies such as frequent blood donation, nutritional deficiencies (i.e., vegan or vegetarian diet), nongastrointestinal blood loss and malabsorption syndromes. ${ }^{[3]}$
It was determined in re-investigation of patients without any pathology endoscopically that 5 patients were blood donors and 1 patient had leech and cupping treatments.

Bidirectional endoscopy is an invasive procedure; however, overall risk of complication is lower in both upper endoscopy and colonoscopy. ${ }^{[3,19]}$ In our study, no complications or mortality secondary to endoscopic procedures were observed in any patient in accordance with the literature.

A limitation of our study was retrospective design. Since we could not access all data, we could not make detailed evaluations. Therefore, further prospective studies under suggestions of the guidelines are required.

\section{CONCLUSION}

Upper and lower GIS endoscopy examinations are important and necessary diagnostic methods in the investigation of the ID etiology. Bidirectional endoscopic examinations according to guideline recommendations increase diagnostic efficiency compared to unidirectional examinations. Phlebotomy and traditional alternative medical treatments that cause blood loss in patients with no pathology should be questioned in the etiology.

\section{ETHICAL DECLARATIONS}

Ethics Committee Approval: The study was carried out with the permission of Local Ethics Committee of Amasya University (approval number: 2020/E.11346).

Informed Consent: All patients signed the free and informed consent form.

\section{Referee Evaluation Process: Externally peer-reviewed.}

Conflict of Interest Statement: The author(s) declared no potential conflicts of interest with respect to the research, authorship, and/or publication of this article.

Financial Disclosure: The authors declared that this study has received no financial support.

Author Contributions: All of the authors declare that they have all participated in the design, execution, and analysis of the paper, and that they have approved the final version.

Note: This study was presented as an oral presentation at the congress of the 16th Anatolian Gastroenterology Days in Şanlıurfa, 11-12 September 2020

\section{REFERENCES}

1. Goddard AF, James MW, Mclntyre AS, et al. Guidelines for the management of iron deficiency anaemia. Gut 2011;60:1309-16.

2. Dickey S, Rockey DC. The natural history of iron deficiency anemia. Am J Med Sci 2019;358:357-62.

3. Ko CW, Siddique SM, Patel A, et al. AGA Clinical Practice Guidelines on the Gastrointestinal Evaluation of Iron Deficiency Anemia. Gastroenterology 2020;159:1085-94.

4. Ünal ÜH, Fidan C, Korkmaz M, Selçuk H. Gastrointestinal endoscopy findings in iron-deficient patients. Turk J Acad Gastroenterol 2012; 3:1136. 
5. Majid S, Salih M, Wasaya R, Jafri M. Predictors of gastrointestinal lesions on endoscopy in iron deficiency anemia without gastrointestinal symptoms. BMC Gastroenterol 2008;8:52.

6. Yaylacı S, Genç AB, Tamer A, Cinemre H, Uslan Mi. Endoscopic examination results in patients with iron deficiency anemia. Medical Journal of Kocaeli 2014; 2:16-9

7. Cetinkaya ZA, Sezikli M, Güzelbulut $F$, et al. Results of gastrointestinal endoscopic examinations in patients with iron deficiency anemia. Dicle Med J 2011;38(2):155-9.

8. DC Rockey, O Altayar, Y Falck-Ytter, D Kalmaz. AGA Technical Review on Gastrointestinal Evaluation of Iron Deficiency Anemia. Gastroenterology 2020;159:1097-119.

9. James MW, Chen CM, Goddard WP, et al. Risk factors for gastrointestinal malignancy in patients with iron-deficiency anaemia. Eur J Gastroenterol Hepatol 2005; 17:1197-203.

10. Brady PG. Iron deficiency anemia: A call for aggresive diagnostic evaluation. Southern Medical J 2007;100(7):966-7.

11. Karnam US, Felder LR, Raskin JB. Prevalence of occult celiac disease in patients with iron-deficiency anemia: a prospective study. South Med J. 2004;97(1):30-4.

12. Hudak L, Jaraisy A, Haj S, et al. An updated systematic review and metaanalysis on the association between Helicobacter pylori infection and iron deficiency anemia. Helicobacter 2017;22.

13. Lee YC, Chiang TH, Chou CK, et al. Association between Helicobacter pylori eradication and gastric cancer incidence: a systematic review and metaanalysis. Gastroenterology 2016;150:1113-24.

14. Malfertheiner $P$, Megraud F, O'Morain C, et al. Current concepts in the management of Helicobacter pylori infection: the Maastricht III Consensus Report. Gut 2007;56(6):772-81.

15. Cardenas VM, Mulla ZD, Ortiz M, Graham DY. Iron deficiency and Helicobacter pylori infection in the United States. Am J Epidemiol. 2006;163(1):127-34.

16. Kaye PV, Garsed K, Ragunath K, et al. The clinical utility and diagnostic yield of routine gastric biopsies in the investigation of iron-deficiency anaemia: a case-control study. Am J Gastroenterol 2008;103:2883e9.

17. Tovey Fl, Godfrey JE, Lewin MR. A gastrectomy population: $25 \mathrm{e} 30$ years on. Postgrad Med J 1990;66:450e6.

18. Beyan C, Beyan E, Kaptan K, Ifran A, Uzar Al. Post-gastrectomy anemia: evaluation of 72 cases with post-gastrectomy anemia. Hematology. 2007;12:81-4.

19. Sieg A, Hachmoeller-Eisenbach U, Eisenbach T. Prospective evaluation of complications in outpatient Gl endoscopy: a survey among German gastroenterologists. Gastrointest Endosc 2001;53:620-7. 